\title{
ALTERNATIF PEMILIHAN BAHAN PIPA UNTUK MENCEGAH KOROSI PADA RAW WATER FILTER MESIN SWD 6TM410RR PLTD HATIVE KECIL
}

\author{
B. J. Camerling \\ Dosen Program Studi Teknik Industri, Fakultas Teknik Universitas Pattimura, Ambon
}

Istawa. A. Abdullah

PLN Wilayah Maluku dan Maluku Utara, Ambon

\begin{abstract}
ABSTRAK
Pusat Listrik Tenaga Diesel (PLTD) adalah pembangkit listrik yang menggunakan sistem mesin pembakaran dalam yang memerlukan sistem pendinginan. Proses pembakaran pada ruang bakar akan menimbulkan panas yang tinggi selama pembakaran berlangsung. Oleh sebab itu untuk menghindari terjadinya kerusakan pada material yang berhubungan langsung dengan proses pembakaran maka diperlukan proses pendinginan. Salah satu Sistem pendinginan pada mesin yang terdapat di PLTD Hative Kecil yaitu yang sistem pendinginan dengan menggunakan media air laut (raw waer cooling system). Sistem pendingin tersebut digunakan untuk mendinginkan minyak pelumas, jacket water, dan intercooler. Raw water cooling system memiliki efisiensi yang lebih tinggi dan dapat mendinginkan secara merata. Adapun kerugian raw water cooling system adalah pada instalasi pemipaan dan komponennya mudah sekali terjadi pengkaratan disebabkan air laut yang bersifat korosif. Raw water cooling system mengalami korosi pada filternya (berbahan stainless steel) sehingga membuat lubanglubang filter menjadi semakin besar. Korosi tersebut mengakibatkan banyak kotoran yang tembus melewati lubang-lubang filter hingga menutupi lubang-lubang tubing pendingin minyak pelumas, jacket water dan intercooler. Tentunya kondisi ini sangat mengganggu kelancaran operasional dan pemeliharaan mesin karena terjadinya penurunan performa, mesin trip akibat over heating dan dapat berdampak pada kerusakan material. Untuk itu dengan adanya permasalahan tersebut maka diadakan penelitian untuk dilakukan pemilihan bahan raw water filter dengan menggunakan bahan pipa sehingga diharapkan Raw water cooling system tidak mengalami korosi pada filternya.
\end{abstract}

Kata Kunci : Raw Water Filter, Pipa PVC (Poly Vinyl Chloride)

\begin{abstract}
The Diesel Power Center (PLTD) is a power plant that uses an internal combustion engine system that requires a cooling system. The combustion process in the combustion chamber will cause high heat during combustion takes place. Therefore to avoid damage to the material that is directly related to the combustion process, the cooling process is needed. One of the cooling systems on the engine contained in the Hative Kecil PLTD is a cooling system using seawater media (raw water cooling system). The cooling system is used to cool lubricating oils, water jackets, and intercoolers. Raw water cooling system has a higher efficiency and can cool evenly. The loss of raw water cooling system is in piping installations and its components are very easy to cause corrosion due to corrosive seawater. The raw water cooling system has a corrosion on the filter (made of stainless steel) so as to make the filter holes even bigger. Corrosion caused a lot of dirt to penetrate through the filter holes to cover the holes in the lubricating oil cooler tubing, water jacket, and intercooler. Surely this condition is very disruptive to the smooth operation and maintenance of the engine due to a decrease in performance, the engine trip due to overheating and can have an impact on material damage. For that reason, with this problem, a study was conducted to select raw water filter material using pipe material so that it is expected that the Raw water cooling system will not corrode the filter.
\end{abstract}

Kata Kunci : Raw Water Filter, PVC Pipe (Poly Vinyl Chloride) 


\section{PENDAHULUAN}

Di era modern seperti sekarang, listrik merupakan salah satu kebutuhan yang pokok bagi kehidupan. Banyak daerah-daerah terpencil di Indonesia yang belum mendapat pasokan energi listrik yang cukup untuk kebutuhan sehari-hari.

Keterbatasan pasokan listrik ini disebabkan penggunaan listrik yang berlebihan dalam kehidupan sehari-hari baik itu di rumah tangga, perusahaan maupun industri. Untuk menanggulangi keterbatasan pasokan listrik ini, maka banyak didirikan pembangkit-pembangkit listrik di Indonesia, salah satunya adalah Pembangkit Listrik Tenaga Diesel (PLTD).

Dimana PLTD Ini menggunakan sistem mesin pembakaran dalam yang memerlukan sistem pendinginan. Proses pembakaran pada ruang bakar akan menimbulkan panas yang tinggi selama pembakaran berlangsung. Oleh sebab itu untuk menghindari terjadinya kerusakan pada material yang berhubungan langsung dengan proses pembakaran maka diperlukan proses pendinginan.

Sistem pendinginan pada mesin PLTD Hative Kecil terdapat dua sistem yaitu yang pertama sistem pendinginan dengan menggunakan media air laut (raw water cooling system) pada Satuan Pembangkit Diesel (SPD) unit I, II, III, IV dan yang kedua radiator cooling system dengan media udara pada SPD unit V. Sistem pendingin tersebut digunakan untuk mendinginkan minyak pelumas, jack et water, dan intercooler.

Raw water cooling system memiliki efisiensi yang lebih tinggi dan dapat mendinginkan secara merata dibandingkan dengan radiator cooling system. Adapun kerugian raw water cooling system adalah pada instalasi pemipaan dan komponennya mudah sekali terjadi pengkaratan disebabkan air laut yang bersifat korosif. Raw water cooling system pada SPD unit I mengalami korosi pada filternya (berbahan stainless steel) sehingga membuat lubang-lubang filter menjadi semakin besar. Korosi tersebut mengakibatkan banyak kotoran yang tembus melewati lubang-lubang filter hingga menutupi lubanglubang tubing pendingin minyak pelumas, jacket water dan intercooler. Tentunya kondisi ini sangat mengganggu kelancaran operasional dan pemeliharaan mesin karena terjadinya penurunan performa, mesin trip akibat over heating dan dapat berdampak pada kerusakan material.

Masalah tersebut juga berdampak pada penurunan performa mesin pembangkin yang dapat menurunkan daya mampu mesin hingga lebih dari 50\% dari daya mampu normalnya, tentunya hal ini berakibat pada kerugian kwh jual. Dari permasalah diatas maka muncul ide untuk membuat raw water filter dengan menggunakan bahan pipa sehingga diharapkan kejadian seperti diatas tidak akan terulang kembali.

Penelitian ini bertujuan untuk membandingkan Biaya pada alternative pemilihan bahan raw water filter, unutk mengetahui perbandingan performansi dan value pada penggunaan alternatif pemilihan bahan raw water filter alternatif awal dan menentukan alternative pemilihan bahan raw water filter terbaik.

\section{LANDASAN TEORI \\ Value Engineering}

Value Engineering adalah suatu sistem yang secara lengkap digunakan untuk mengidentifikasi dan berhubungan dengan faktor-faktor yang mempengaruhi biaya maupun usaha dalam suatu produk, proses ataupun pelayanan (Lawrence, 1972:3). Karakteristik Value Engineering adalah sebagai berikut :

1. Berorientasi pada sistem, yang artinya melihat suatu produk atau proyek secara menyeluruh dengan melihat keterkaitan antar komponen dan memperhatikan fungsi dan nilai dari masing-masing komponen yang terlibat.

2. Bersifat multi disiplin, yang dilakukan oleh beberapa ahli yang berkompeten dan berpengalaman dibidangnya.

3. Merupakan suatu teknik manajemen yang diaplikasikan untuk mencari efisiensi biaya proyek atau produk tanpa mengorbankan mutu, keandalan dan performansi.

4. Berorientasi pada fungsi, artinya berusaha memenuhi fungsi-fungsi yang diperlukan dan sebanding dengan nilai yang diperoleh.

Berdasarkan prinsip dasar Value Engineering, tujuan utama perancangan produk adalah untuk memenuhi kebutuhan dan memberikan kepuasan kepada pemakai produk. Oleh karena itu, para perancang seharusnya tidak memberikan fungsi-fungsi pada produk secara berlebihan, karena hal ini akan mengakibatkan penambahan biaya. Dengan demikian, tujuan Value Engineering adalah untuk mendapatkan nilai semaksimal mungkin. Secara sederhana, nilai dapat dicari dengan menggunakan rumus: 


$$
\begin{array}{ll}
\text { Dimana : } & \mathrm{V}=\text { Value } \\
& \mathrm{P}=\text { Peformance } \\
& \mathrm{C}=\text { Cost }
\end{array}
$$

.Meskipun terdapat banyak pengertian mengenai nilai, seperti nilai etis, nilai moral dan sebagainya, tetapi pada Value Engineering hanya mempertimbangkan nilai-nilai yang mencangkup :

1. Nilai Guna

Memperlihatkan tingkat kegunaan dan pelayanan yang dapat diberikan oleh suatu produk.

2. Nilai Kebanggaan

Nilai ini menunjukkan seberapa jauh suatu produk mempunyai kemampuan untuk menarik dan mendorong para konsumen untuk memilikinya.

3. Nilai Tukar

Nilai ini menunjukkan seberapa besar konsumen mau berkorban atau mengeluarkan biaya untuk mendapatkan suatu produk.

4. Nilai Biaya

Nilai ini menunjukkan seberapa besar biaya yang diperlukan untuk menghasilkan produk dan untuk memenuhi seluruh fungsi yang diharapkan.

Fungsi dari Value Engineering dibedakan menjadi dua macam yaitu :

1. Fungsi Primer

Fungsi primer merupakan dasar atau ketentuan yang diperlukan untuk dapat terwujudnya suatu item dan merupakan jawaban atas pertanyaan "Apa yang dilakukan?". Suatu item proyek atau produk dapat memiliki lebih dari satu fungsi primer, tergantung dari kebutuhan pemakainya.

2. Fungsi Sekunder

Fungsi sekunder merupakan jawaban atas pertanyaan “Apalagi yang akan dikerjakan?”. Fungsi ini merupakan fungsi penunjang yang sering kali tidak begitu penting bagi penampilan fungsi utama.

\section{Matrik Kelayakan}

Matrik kelayakan merupakan salah satu langkah yang diambil sebagai pertimbangan dalam pemilihan alternatif yang diusulkan. Kriteria kelayakan tergantung dari proyek atau produk yang diusulkan. Tiap-tiap alternatif akan dinilai dengan kriteria di mana penilai akan memberikan suatu penilaian dengan nilai antara 0 sampai dengan 10. Untuk mewujudkan suatu matrik kelayakan, maka

\begin{tabular}{|c|c|c|c|c|c|c|c|c|}
\hline \multirow{3}{*}{ NO. } & \multirow{3}{*}{ ALTERNATIF } & \multicolumn{5}{|c|}{ Matrik Kelayakan } & \multirow{3}{*}{ TOTAL } & \multirow{3}{*}{ RANKING } \\
\hline & & \multicolumn{5}{|c|}{ KRITERIA } & & \\
\hline & & $\mathbf{A}$ & B & C & $\ldots$ & $\mathbf{n}$ & & \\
\hline 1 & Alternatif 1 & & & & & & & \\
\hline 2 & Alternatif 2 & & & & & & & \\
\hline 3 & Alternatif 3 & & & & & & & \\
\hline . & . & & & & & & & \\
\hline . & . & & & & & & & \\
\hline $\mathrm{n}$ & Alternatif $n$ & & & & & & & \\
\hline
\end{tabular}
dibuat tabel matriks kelayakan di mana bagian kolom atas terdiri dari kriteria-kriteria, sedangkan kolom sebelah kiri, terdiri dari alternatif-alternatif yang akan dinilai.

\section{Matrik Evaluasi}

Matrik evaluasi adalah suatu teknik pengambilan keputusan yang dapat menghubungkan kriteria kualitatif (tidak dapat diukur) dengan kriteria kuantitatif (dapat diukur). Kriteria-kriteria ini dapat berupa biaya, kekuatan, kemudahan operasi, dan sebagainya. Pada matriks evaluasi dilakukan penilaian terhadap alternatif-alternatif yang ditampilkan dan penilaian ini dilakukan dengan mempertimbangkan kriteria-

\begin{tabular}{|c|c|c|c|c|c|c|c|c|}
\hline \multirow{2}{*}{ NO. } & \multirow{2}{*}{ ALTERNATIF } & \multicolumn{5}{|c|}{ KRITERIA } & \multirow[t]{2}{*}{ TOTAL } & \multirow[t]{2}{*}{ RANKING } \\
\hline & & $\mathbf{A}$ & $\mathbf{B}$ & $\mathbf{C}$ & $\ldots$ & $\mathbf{n}$ & & \\
\hline 1 & Alternatif 1 & & & & & & & \\
\hline 2 & Alternatif 2 & & & & & & & \\
\hline 3 & Alternatif 3 & & & & & & & \\
\hline . & 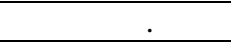 & & & & & & & \\
\hline . & . & & & & & & & \\
\hline $\mathrm{n}$ & Alternatif $n$ & & & & & & & \\
\hline
\end{tabular}
kriteria yang telah ditetapkan.

Matrik Evaluasi 


\section{Analisa Hirarki}

Analisa ini pertama kali dikembangkan oleh seorang ahli matematika bernama Thomas L. Saaty. Metode ini sudah banyak digunakan secara luas di seluruh dunia. Prinsip-prinsip analisa Hirarki adalah prinsip menyusun hirarki, prinsip menetapkan prioritas dan prinsip konsistensi logis.

Dalam analisa hirarki, prinsip penyusunan hirarki digunakan untuk merinci suatu keadaan kompleks ke dalam komponen-komponennya, kemudian mengatur bagian-bagian komponen tersebut dalam bentuk hirarki. Pada analisa hirarki, masalah yang paling utama adalah melakukan perbandingan berpasangan (judgement) antar faktor pada suatu hirarki. Setelah dilakukannya penilaian perbandingan berpasangan, maka sebagai hasil analisis adalah menentukan faktor mana yang memiliki prioritas tertinggi. Langkah selanjutnya adalah mengadakan pengujian konsistensi terhadap hasil analisis prioritas tertinggi di atas.

\section{Teknik Pengukuran Data Skor Alternatif}

Hasil perbandingan berpasangan menyajikan nilai bobot lokal $(w)$ bagi setiap alternatif, sub krteria, atau kriteria. Kombinasi dari bobot lokal ini membentuk skor akhir atau prioritas alternatif. Jika A menyatakan altenatif, $\operatorname{Pr}\left(\mathrm{A}_{\mathrm{i}}\right)$ adalah prioritas alternatif ke-i dan $w_{\mathrm{i}}$ merupakan bobot lokalnya, maka

$$
\operatorname{Pr}\left(\Lambda_{i}\right)-\sum_{i=1}^{k} w_{i} \operatorname{Pr}_{i}\left(\Lambda_{i}\right)
$$

\section{Analisis Sensitivitas}

Analisis ini menentukan sejauh mana keputusan yang sama akan bertahan dengan perubahan tingkat prioritas. Proses ini dilakukan dengan merubah-rubah nilai bobot kriteria atau sub kriteria. Hasilnya akan menunjukan interval skor (minimum dan maksimum) dari setiap kriteria atau sub kriteria yang akan merubah keputusan.

\section{Sistem Pendingin Mesin}

Sistem air pendingin atau pendinginan berguna untuk mengambil sebagian panas dari bagian-bagian tertentu di mesin. Panas yang menyebabkan temperatur tinggi tersebut dikarenakan oleh pembakaran bahan bakar diruang bakar. Untuk menjaga agar pada bagian-bagian tadi tidak terjadi beban panas berlebih dan beban mekanik berlebih mengakibatkan toleransi serta pelumasan tidak berfungsi seperti seharusnya.

Pendinginan dapat terjadi dengan dua cara yaitu pendinginan secara alami dan pendinginan secara paksa. Pendinginan secara alami yaitu proses pendinginan yang berlangsung dengan sendirinya tanpa turut campur tangan manusia. Sedangkan proses pendinginan secara paksa yaitu proses pendinginan yang berlangsung dengan turut campur tangan manusia. Selain itu menurut siklusnya, proses pendinginan terbagi atas dua bagian yaitu:

1. Pendinginan Terbuka

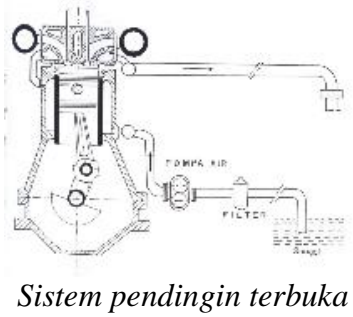

\section{Pendinginan Tertutup}

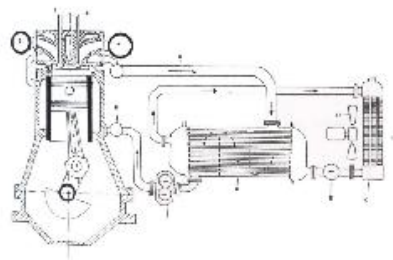

Sistem pendingin Tertutup 
3. Raw Water Cooling System

Raw water cooling system merupakan sistem pendingin terpisah, dalam pengertian masing-masing bagian yang didinginkan disediakan cooler tersendiri dengan fluida (air laut) sebagai media pendinginnya. Proses pendinginannya dengan cara air laut diambil dari dermaga melalui katup hisap bawah dengan menggunakan pompa, kemudian air laut disaring melalui filter, selanjutnya air laut disirkulasikan ke seluruh bagian pendingin mesin yaitu pendingin minyak pelumas, pendingin jacket water dan intercooler, setelah itu air laut dibuang ke saluran pembuangan menuju laut. Skematik raw water cooling system tampak pada gambar

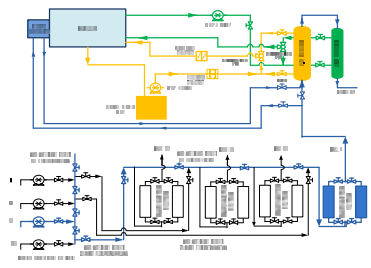

Raw Water Cooling System PLTD Hative Kecil

\section{METODE PENELITIAN}

\section{Variabel dan Definisi Operasional}

Variabel keputusan dapat dinotasikan dengan lambang X. Yang termasuk dalam indikator variabel keputusan dalam penilitian adalah sebagai berikut :

a. Biaya Pembelian Material $\left(\mathrm{X}_{1}\right)$

b. Umur Pakai $\left(\mathrm{X}_{2}\right)$

c. Keandalan Mesin $\left(\mathrm{X}_{3}\right)$

Variabel keputusan merupakan suatu indikator untuk mencapai variabel tujuan. Yang mana variabel tujuan adalah untuk Performansi Raw Water Filter.

\section{Metode Analisa Data}

Hasil dari pengolahan data selanjutnya dianalisa dan dievaluasi menggunakan metoda Value Engineering untuk mengetahui jenis bahan raw water filter terbaik yang akan digunakan. Berikut ini merupakan flowchart dari penelitian ini.

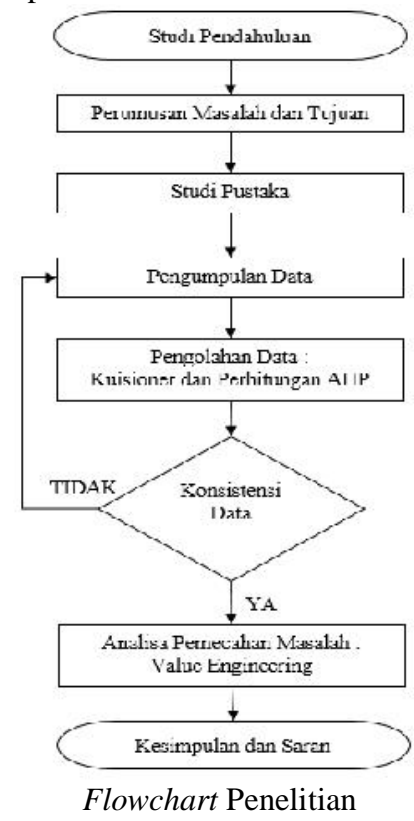

\section{HASIL DAN PEMBAHASAN}

\section{Penentuan Kriteria}

Penentuan kriteria pada awalnya mengambil kriteria pemilihan bahan raw water filter minyak menurut penulis jurnal setelah itu dilanjutkan dengan metode wawancara terhadap para staff PLTD 
Hative Kecil yang berkompeten dalam aspek teknis yang menyangkut pengoeprasian mesin. Jurnal-jurnal tersebut antara lain adalah :

Jurnal Kriteria
\begin{tabular}{|c|l|l|l|}
\hline NO. & \multicolumn{1}{|c|}{ JURNAL } & \multicolumn{1}{|c|}{ KRITERIA } \\
\hline 1 & $\begin{array}{l}\text { KONSUMSI BBM UNTUK PEMBANGKIT LISTRIK } \\
\text { DI INDONESIA; KECENDERUNGAN, } \\
\text { PERMASALAHAN DAN SOLUSINYA }\end{array}$ & BIAYA POKOK PRODUKSI & ZAINAL ARIFIN \\
\hline 2 & $\begin{array}{l}\text { ENERGI TERBARUKAN DALAM PEMBANGUNAN } \\
\text { BERKELANJUTAN }\end{array}$ & ENERGI BARU TERBARUKAN & ABUBAKAR LUBIS \\
\hline 3 & $\begin{array}{l}\text { PENGEMBANGAN KNOWLEDGE SHARING PADA } \\
\text { PENINGKATAN KETERHANDALAN }\end{array}$ & KEANDALAN & $\begin{array}{l}\text { TEDJO SUKMONO, } \\
\text { PRATIKTO, SUDITO } \\
\text { SUPARMAN, PURNOMO } \\
\text { BUDI SANTOSO }\end{array}$ \\
\hline 4 & $\begin{array}{l}\text { PEMBUATAN DAN UJ KUALLTAS BIODIESEL } \\
\text { DARI MINYAKJELANTAH }\end{array}$ & RAMAH LINGKUNGAN & SYAMSIDAR HS \\
\hline
\end{tabular}

Penentuan kriteria didasarkan pada hasil penilaian responden berdasarkan kuisioner yang diedarkan. Responden berjumlah 13 orang keseluruhan diambil dari 13 pegawai PLTD tanpa menggunakan sampling karena jumlah populasi yang kecil. Pengetahuan responden pada aspek teknis yang menyangkut pengoperasian dan pemeliharaan mesin dinilai sama karena terdapat media rapat bulanan sehingga pengetahuan yang didapat merata. Berdasarkan hasil penilaian responden melalui kuisioner yang diedarkan untuk penentuan kriteria, didapat kriteria terpilih sebagai berikut :

Penentuan Kriteria

\begin{tabular}{|c|c|c|c|c|c|c|}
\hline NO & KRITERIA & STP & TP & CP & $\mathbf{P}$ & SP \\
\hline \multirow{2}{*}{1} & Menurut Zainal Arifin & & & & & \\
\hline & - Biaya Pokok Produksi & & 4 & 6 & 2 & 1 \\
\hline \multirow{2}{*}{2} & Menurut Tedjo Sukmoro dkk & & & & & \\
\hline & - Keandalan Mesin & & & 2 & 2 & 9 \\
\hline \multirow{2}{*}{3} & Menurut Syamsidar HS & & & & & \\
\hline & - Ramah Lingkungan & & 3 & 5 & 2 & 2 \\
\hline \multirow{3}{*}{4} & Menurut Pendapat Pegawai & & & & & \\
\hline & Biaya pengadaan material & & & 1 & 2 & 10 \\
\hline & Umur pakai Spare Part & & & 1 & 1 & 11 \\
\hline
\end{tabular}

Berdasarkan hasil pada tabel penilaian responden pada kuisioner yang diedarkan, maka kriteria terpilih (mendapat nilai rata-rata PENTING atauSANGAT PENTING) adalah sebagai berikut :

1. Biaya Pembelian Material

Biaya Pembelian Material adalah biaya yang harus dikeluarkan oleh PLN untuk membeli 1 set raw water filter

2. Ramah Lingkungan

Ramah Lingkungan merupakan program yang bertujuan untuk tujuan kelestarian lingkungan dan kesehatan lingkungan di wilayah dekat sumber produksi PLN. Penggunaan jenis bahan raw water filter yang berbeda akan menghasilkan polusi atau sisa pemraw water filteran yang berbeda-beda.

3. Umur Pakai Spare Part

Umur Pakai Spare Part adalah lama spare part dapat digunakan secara normal sehingga hasil produksi yang diperoleh maksimal. Penggunaan jenis bahan raw water filter sangat menentukan umur pakai spare part.

4. Keandalan Mesin

Keandalan Mesin adalah kemampuan suatu satuan pembangkit diesel untuk beroperasi secara normal dalam waktu tertentu dan menghasilkan produk listrik dengan maksimal.

5. Biaya Pemeliharaan

Biaya Pemeliharaan adalah biaya yang harus dikeluarkan PLN untuk melakukan suatu perbaikan atau tindakan korektif pada komponen mesin mengalami kerusakan.

\section{Penentuan Tingkat Prioritas Kriteria}

Penentuan Tingkat Prioritas Kriteria Berdasarkan Alternatif Awal

\begin{tabular}{|c|c|c|c|c|c|c|c|c|c|c|c|c|c|c|}
\hline \multirow{2}{*}{ KRITERIA } & \multicolumn{14}{|c|}{ RESPONDEN AWAL } \\
\hline & 01 & 02 & 03 & 04 & 05 & 06 & 07 & 08 & 09 & 10 & 11 & 12 & 13 & SKOR \\
\hline Umur Pakai Spare Part & 6 & 5 & 4 & 6 & 4 & 6 & 4 & 4 & 5 & 5 & 5 & 4 & 4 & 62 \\
\hline Biaya Produksi (Pembelian) & 4 & 5 & 5 & 6 & 4 & 6 & 4 & 4 & 6 & 5 & 6 & 5 & 6 & 66 \\
\hline Ramah Lingkungan & 6 & 6 & 5 & 4 & 6 & 4 & 6 & 5 & 4 & 5 & 4 & 5 & 4 & 64 \\
\hline Keandalan Mesin & 6 & 4 & 3 & 5 & 4 & 6 & 6 & 5 & 4 & 5 & 5 & 5 & 5 & 63 \\
\hline Biaya Pemeliharaan & 6 & 4 & 5 & 4 & 6 & 4 & 6 & 5 & 4 & 5 & 4 & 5 & 4 & 62 \\
\hline
\end{tabular}


Berdasarkan hasil penilaian responden berdasarkan kuisioner yang diedarkan, maka urutan tingkat prioritas dari alternatif awal adalah sebagai berikut :

1. Biaya Produksi / Pembelian Material

2. Ramah Lingkungan

3. Umur Pakai Spare Part

4. Keandalan Mesin

5. Biaya Pemeliharaan

\section{Penentuan Tingkat Kepentingan Kriteria}

Tingkat Kepentingan Masing -Masing Kriteria Untuk Alternatif Awal

\begin{tabular}{|c|c|c|c|c|c|c|c|c|c|c|c|c|c|c|c|c|}
\hline \multirow{2}{*}{ KRITERIA } & \multirow{2}{*}{$\begin{array}{c}\text { TINGKAT } \\
\text { PEMENUHAN }\end{array}$} & \multicolumn{13}{|c|}{ RESPONDEN AWAL } & \multirow{2}{*}{ FREK } & \multirow{2}{*}{ TINGKAT } \\
\hline & & 01 & 02 & 03 & 04 & 05 & 06 & 07 & 08 & 09 & 10 & 11 & 12 & 13 & & \\
\hline \multirow{4}{*}{ Biaya Pokok Produksi } & Tinggi & & & & & & & & & & & & & & 0 & \\
\hline & Cukup Tinggi & $\mathrm{v}$ & $\mathrm{v}$ & & & $\mathrm{v}$ & $\mathrm{v}$ & $\mathrm{v}$ & $\mathrm{v}$ & $\mathrm{v}$ & & & & & 7 & CT \\
\hline & Cukup Rendah & & & & $\mathrm{v}$ & & & & & & $v$ & $v$ & $\mathrm{v}$ & $\mathrm{v}$ & 5 & \\
\hline & Rendah & & & $\mathrm{v}$ & & & & & & & & & & & 1 & \\
\hline \multirow{4}{*}{ Ramah Lingkungan } & Tinggi & & & & & & & & & & & & & & 0 & \\
\hline & Cukup Tinggi & & & & & & & & & & & & & & 0 & \\
\hline & Cukup Rendah & $\mathrm{v}$ & $\mathrm{v}$ & $\mathrm{v}$ & $\mathrm{v}$ & & $\mathrm{v}$ & & $\mathrm{v}$ & $\mathrm{v}$ & $\mathrm{v}$ & & $\mathrm{v}$ & $\mathrm{v}$ & 10 & CR \\
\hline & Rendah & & & & & $v$ & & $v$ & & & & $v$ & & & 3 & \\
\hline \multirow{4}{*}{ Umur Pakai Spare Part } & Tinggi & & & & & & & & & & & & $v$ & $\mathrm{v}$ & 2 & \\
\hline & Cukup Tinggi & & $\mathrm{v}$ & $\mathrm{v}$ & $\mathrm{v}$ & $\mathrm{v}$ & $\mathrm{v}$ & $\mathrm{v}$ & $\mathrm{v}$ & $\mathrm{v}$ & $\mathrm{v}$ & $\mathrm{v}$ & & & 10 & CT \\
\hline & Cukup Rendah & $\mathrm{v}$ & & & & & & & & & & & & & 1 & \\
\hline & \begin{tabular}{|l|} 
Rendah \\
\end{tabular} & & & & & & & & & & & & & & 0 & \\
\hline \multirow{4}{*}{ Keandalan Mesin } & Tinggi & & & & & & & & & & & & & & 0 & \\
\hline & Cukup Tinggi & $\mathrm{v}$ & $v$ & $\mathrm{v}$ & $v$ & $\mathrm{v}$ & $\mathrm{v}$ & $v$ & $\mathrm{v}$ & $\mathrm{v}$ & $v$ & $v$ & $\mathrm{v}$ & $\mathrm{v}$ & 13 & CT \\
\hline & Cukup Rendah & & & & & & & & & & & & & & 0 & \\
\hline & Rendah & & & & & & & & & & & & & & 0 & \\
\hline \multirow{4}{*}{ Biaya Pemeliharaan } & Tinggi & & & & & & & & & & & & & & 0 & \\
\hline & Cukup Tinggi & $\mathrm{v}$ & $\mathrm{v}$ & $\mathrm{v}$ & & $\mathrm{v}$ & $v$ & $v$ & v & $v$ & & $\mathrm{v}$ & & & 9 & CT \\
\hline & Cukup Rendah & & & & $v$ & & & & & & $v$ & & $\mathrm{v}$ & $\mathrm{v}$ & 4 & \\
\hline & Rendah & & & & & & & & & & & & & & 0 & \\
\hline
\end{tabular}

Keterangan : $\mathrm{T}=$ Tinggi, $\mathrm{CT}=$ Cukup Tinggi, $\mathrm{CR}=$ Cukup Rendah, $\mathrm{R}=$ Rendah

Berdasarkan hasil penilaian responden diatas, maka tingkat kepentingan dari kriteria penilaian untuk alternatif awal adalah sebagai berikut :

1. Biaya Pembelian Material Cukup Tinggi

2. Ramah Lingkungan Cukup Rendah

3. Umur Pakai Spare Part Cukup Rendah

4. Keandalan Mesin Cukup Tinggi

5. Biaya Pemeliharaan Cukup Tinggi

\section{Pilihan Alternatif}

Terdapat 3 jenis alternatif yang dapat diusulkan penggunaannya yaitu

1. Alternatif 1 Penggunaan Pipa jenis Stainless steel

Pipa jenis ini adalah pipa dengan jenis baja yang tahan terhadap oksidasi

2. Alternatif 2 Penggunaan Pipa PVC Type AW

Pipa tipe AW merupakan pipa paling tebal yang mampu menahan tekanan hingga $10 \mathrm{~kg} / \mathrm{cm}^{2}$. Pipa jenis ini baik untuk saluran air minum, terutama bagian penghisapan hingga saluran air ke keran.

3. Alternatif 2 Penggunaan Pipa PVC Type D

Pipa tipe D merupakan pipa dengan ketebalan sedang yang mampu menahan tekanan hingga 5 $\mathrm{kg} / \mathrm{cm}^{2}$. Pipa jenis ini cocok untuk saluran pembuangan dan limbah.

\section{Tahap Analisa}

Pada tahap analisa, akan dilakukan beberapa analisa terhadap alternatif-alternatif penggunaan bahan raw water filter utama. Analisa tersebut meliputi :

1. Perhitungan penilaian dengan menggunakan matriks kelayakan

Matrik kelayakan merupakan salah satu langkah yang diambil sebagai pertimbangan dalam pemilihan alternatif yang diusulkan. Kriteria kelayakan tergantung dari proyek atau produk yang diusulkan. Tiap-tiap alternatif akan dinilai dengan kriteria di mana penilai akan memberikan suatu penilaian dengan nilai antara 0 sampai dengan 10. Untuk mewujudkan suatu matrik kelayakan, maka dibuat tabel matriks kelayakan di mana bagian kolom atas terdiri dari kriteria-kriteria, sedangkan kolom sebelah kiri, terdiri dari alternatif-alternatif yang akan dinilai. 
2. Analisa pembobotan

Penilaian perbandingan berpasangan dilakukan pada elemen-elemen pada suatu tingkat hirarki. Penilaian ini dilakukan dengan memberikan bobot numerik berdasarkan perbandingan berpasangan antara satu elemen dengan elemen lainnya. Hasil perbandingan tersebut dibentuk menjadi matriks bujur sangkar dengan ordo sesuai jumlah elemen pada tingkat hirarki tersebut. Skala penilaian yang digunakan untuk perbandingan berpasangan dapat dilihat pada tabel 2.3.

3. Perhitungan performansi dengan menggunakan matriks evaluasi

Matrik evaluasi adalah suatu teknik pengambilan keputusan yang dapat menghubungkan kriteria kualitatif (tidak dapat diukur) dengan kriteria kuantitatif (dapat diukur). Kriteria-kriteria ini dapat berupa biaya, kekuatan, kemudahan operasi, dan sebagainya. Pada matriks evaluasi dilakukan penilaian terhadap alternatif-alternatif yang ditampilkan dan penilaian ini dilakukan dengan mempertimbangkan kriteria-kriteria yang telah ditetapkan. Langkah-langkah penilaian dengan menggunakan matriks evaluasi ini adalah sebagai berikut :

a. Menentukan alternatif desain yang akan dievaluasi

b. Menetapkan kriteria-kriteria yang berpengaruh

c. Menetapkan bobot masing-masing kriteria

d. Memberikan penilaian pada setiap alternatif terhadap masing-masing kriteria dan penilaian dilakukan oleh beberapa orang dengan persyaratan tertentu

e. Menghitung nilai total masing-masing alternatif

f. Memilih alternatif terbaik berdasarkan total nilai terbesar

\section{Analisa Keuntungan Dan Kerugian}

Responden berjumlah 13 orang keseluruhan diambil dari 13 pegawai PLTD tanpa menggunakan sampling karena jumlah populasi yang kecil. Pengetahuan responden pada aspek teknis yang menyangkut pengeoperasian dan pemeliharaan mesin dinilai sama karena terdapat media rapat bulanan sehingga pengetahuan yang didapat merata. Pada tahap ini akan diberikan kuisioner yang berisikan pertanyaan tentang urutan tingkat prioritas kriteria dan memilih tingkat kepentingan berdasarkan tingkat prioritas yang telah dipilih. Hasil dari pemilihan tingkat prioritas inilah yang nantinya akan digunakan untuk penentuan bobot kriteria yang dipakai analisa matriks evaluasi. Berdasarkan hasil penentuan prioritas kriteria pada tabel diatas, maka urutan kriteria adalah sebagai berikut :

1. Biaya Pembelian Material

2. Ramah Lingkungan

3. Umur Pakai Spare Part

4. Keandalan Mesin

5. Biaya Pemeliharaan

Tingkat Kepentingan Masing-Masing Kriteria Untuk Alternatif 1

\begin{tabular}{|c|c|c|c|c|c|c|c|c|c|c|c|c|c|c|c|c|}
\hline \multirow{2}{*}{ KRITERIA } & \multirow{2}{*}{$\begin{array}{c}\text { TINGKAT } \\
\text { PEMENUHAN }\end{array}$} & \multicolumn{13}{|c|}{ RESPONDEN AWAL } & \multirow{2}{*}{ FREK } & \multirow{2}{*}{ TINGKAT } \\
\hline & & 01 & 02 & 03 & 04 & 05 & 06 & 07 & 08 & 09 & 10 & 11 & 12 & 13 & & \\
\hline \multirow{4}{*}{ Biaya Pokok Produksi } & Tinggi & & & & & & & & & & & & & & 0 & \\
\hline & Cukup Tinggi & $v$ & $v$ & & & $v$ & $v$ & $v$ & $v$ & v & & & & & 7 & CT \\
\hline & Cukup Rendah & & & & $\mathrm{v}$ & & & & & & $v$ & v & v & $\mathrm{v}$ & 5 & \\
\hline & \begin{tabular}{|l|} 
Rendah \\
\end{tabular} & & & $\mathrm{v}$ & & & & & & & & & & & 1 & \\
\hline \multirow{4}{*}{ Ramah Lingkungan } & Tinggi & & & & & & & & & & & & & & 0 & \\
\hline & Cukup Tinggi & & & & & & & & & & & & & & 0 & \\
\hline & Cukup Rendah & $\mathrm{v}$ & $\mathrm{v}$ & $\mathrm{v}$ & v & & v & & v & v & v & & $\mathrm{v}$ & $\mathrm{v}$ & 10 & CR \\
\hline & \begin{tabular}{|l|} 
Rendah \\
\end{tabular} & & & & & $\mathrm{v}$ & & $\mathrm{v}$ & & & & $\mathrm{v}$ & & & 3 & \\
\hline \multirow{4}{*}{ Umur Pakai Spare Part } & Tinggi & & & & & & & & & & & & $\mathrm{v}$ & $\mathrm{v}$ & 2 & \\
\hline & Cukup Tinggi & & v & v & v & v & v & v & v & v & v & v & & & 10 & CT \\
\hline & Cukup Rendah & $v$ & & & & & & & & & & & & & 1 & \\
\hline & \begin{tabular}{|l|} 
Rendah \\
\end{tabular} & & & & & & & & & & & & & & 0 & \\
\hline \multirow{4}{*}{ Keandalan Mesin } & Tinggi & & & & & & & & & & & & & & 0 & \\
\hline & Cukup Tinggi & $\mathrm{v}$ & $\mathrm{v}$ & $\mathrm{v}$ & $\mathrm{v}$ & v & v & $v$ & $\mathrm{v}$ & $\mathrm{v}$ & v & v & $\mathrm{v}$ & $\mathrm{v}$ & 13 & CT \\
\hline & Cukup Rendah & & & & & & & & & & & & & & 0 & \\
\hline & \begin{tabular}{|l|} 
Rendah \\
\end{tabular} & & & & & & & & & & & & & & 0 & \\
\hline \multirow{4}{*}{ Biaya Pemeliharaan } & Tinggi & & & & & & & & & & & & & & 0 & \\
\hline & Cukup Tinggi & $v$ & $\mathrm{v}$ & $\mathrm{v}$ & & $\mathrm{v}$ & $v$ & $v$ & v & 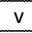 & & $v$ & & & 9 & CT \\
\hline & Cukup Rendah & & & & v & & & & & & v & & v & v & 4 & \\
\hline & Rendah & & & & & & & & & & & & & & 0 & \\
\hline
\end{tabular}

Keterangan : $\mathrm{T}=$ Tinggi, $\mathrm{CT}=$ Cukup Tinggi, $\mathrm{CR}=$ Cukup Rendah, $\mathrm{R}=$ Rendah 
Tingkat Kepentingan Masing-Masing Kriteria Untuk Alternatif 2 (PVC Type AW)

\begin{tabular}{|c|c|c|c|c|c|c|c|c|c|c|c|c|c|c|c|c|}
\hline \multirow{2}{*}{ KRITERIA } & \multirow{2}{*}{$\begin{array}{c}\text { TINGKAT } \\
\text { PEMENUHAN }\end{array}$} & \multicolumn{13}{|c|}{ RESPONDEN AWAL } & \multirow{2}{*}{ FREK } & \multirow{2}{*}{ TINGKAT } \\
\hline & & 01 & 02 & To3 & 04 & 05 & 06 & 07 & 08 & 09 & 10 & 11 & 12 & 13 & & \\
\hline \multirow{4}{*}{ Biaya Produksi } & Tinggi & & & & & & & & & & & & & & 0 & \\
\hline & Cukup Tinggi & & & & & & & & & & & & & & 0 & \\
\hline & Cukup Rendah & & & & v & & $\mathrm{v}$ & $v$ & & $\mathrm{v}$ & & v & $v$ & v & 7 & CR \\
\hline & \begin{tabular}{|l|} 
Rendah \\
\end{tabular} & $\mathrm{v}$ & $\mathrm{v}$ & $\mathrm{v}$ & & $\mathrm{v}$ & & & $\mathrm{v}$ & & $\mathrm{v}$ & & & & 6 & \\
\hline \multirow{4}{*}{ Ramah Lingkungan } & Tinggi & & & & & & & & & & & & & & 0 & \\
\hline & Cukup Tinggi & v & v & & & & & & & & & $\mathrm{v}$ & & $\mathrm{v}$ & 4 & \\
\hline & Cukup Rendah & & & v & v & v & v & v & v & v & $\mathrm{v}$ & & v & & 9 & CR \\
\hline & Rendah & & & & & & & & & & & & & & 0 & \\
\hline \multirow{4}{*}{ Umur Pakai Spare Part } & Tinggi & & & & & & & & v & & & & $\mathrm{v}$ & $\mathrm{v}$ & 3 & \\
\hline & Cukup Tinggi & $\mathrm{v}$ & $\mathrm{v}$ & $\mathrm{v}$ & $\mathrm{v}$ & v & $\mathrm{v}$ & $\mathrm{v}$ & & $\mathrm{v}$ & v & v & & & 10 & CT \\
\hline & Cukup Rendah & & & & & & & & & & & & & & 1 & \\
\hline & Rendah & & & & & & & & & & & & & & 0 & \\
\hline \multirow{4}{*}{ Keandalan Mesin } & Tinggi & & & & & & & & & & v & & v & $\mathrm{v}$ & 3 & \\
\hline & \begin{tabular}{|l|} 
Cukup Tinggi \\
\end{tabular} & v & v & $v$ & $\mathrm{v}$ & v & $\mathrm{v}$ & $v$ & v & v & & v & & & 10 & CT \\
\hline & Cukup Rendah & & & & & & & & & & & & & & 0 & \\
\hline & Rendah & & & & & & & & & & & & & & 0 & \\
\hline \multirow{4}{*}{ Biaya Pemeliharaan } & Tinggi & & & & & & & & & & & & & & 0 & \\
\hline & Cukup Tinggi & & & & & & & & & & & & & & 0 & \\
\hline & Cukup Rendah & & & & & & & & & & & & & & 0 & \\
\hline & \begin{tabular}{|l|} 
Rendah \\
\end{tabular} & $\mathrm{v}$ & $\mathrm{v}$ & v & v & $\mathrm{v}$ & v & $\mathrm{v}$ & $\mathrm{v}$ & v & $\mathrm{v}$ & $\mathrm{v}$ & v & v & 13 & $\mathbf{R}$ \\
\hline
\end{tabular}

Tingkat Kepentingan Masing-Masing Kriteria Untuk Alternatif 3 (PVC Type D)

\begin{tabular}{|c|c|c|c|c|c|c|c|c|c|c|c|c|c|c|c|c|}
\hline \multirow{2}{*}{ KRITERIA } & \multirow{2}{*}{$\begin{array}{c}\text { TINGKAT } \\
\text { PEMENUHAN }\end{array}$} & \multicolumn{13}{|c|}{ RESPONDEN AWAL } & \multirow{2}{*}{ FREK } & \multirow{2}{*}{ TINGKAT } \\
\hline & & 01 & 02 & 03 & 04 & 05 & 06 & 07 & 08 & 09 & 10 & 11 & 12 & 13 & & \\
\hline \multirow{4}{*}{ Biaya Produksi } & Tinggi & & & & & & & & & & & & & & 0 & \\
\hline & Cukup Tinggi & & & & & & & & & & & & & & 0 & \\
\hline & Cukup Rendah & & & & & & $\mathrm{v}$ & $\mathrm{v}$ & & $\mathrm{v}$ & & $\mathrm{v}$ & & $\mathrm{v}$ & 5 & \\
\hline & Rendah & $\mathrm{v}$ & $\mathrm{v}$ & $\mathrm{v}$ & $\mathrm{v}$ & $\mathrm{v}$ & & & $\mathrm{v}$ & & $\mathrm{v}$ & & $\mathrm{v}$ & & 8 & $\mathbf{R}$ \\
\hline \multirow{4}{*}{ Ramah Lingkungan } & Tinggi & & & & & & & & & & & & & & 0 & \\
\hline & Cukup Tinggi & $\mathrm{v}$ & $\mathrm{v}$ & & & & & & & & & $\mathrm{v}$ & & $\mathrm{v}$ & 4 & \\
\hline & Cukup Rendah & & & $\mathrm{v}$ & v & v & v & $\mathrm{v}$ & $\mathrm{v}$ & $\mathrm{v}$ & $\mathrm{v}$ & & $\mathrm{v}$ & & 9 & CR \\
\hline & Rendah & & & & & & & & & & & & & & 0 & \\
\hline \multirow{4}{*}{ Umur Pakai Spare Part } & Tinggi & & & & & & & & & & & & $\mathrm{v}$ & & 1 & \\
\hline & Cukup Tinggi & & & & & & & & $\mathrm{v}$ & & & $\mathrm{v}$ & & & 2 & \\
\hline & Cukup Rendah & $\mathrm{v}$ & $\mathrm{v}$ & $\mathrm{v}$ & $\mathrm{v}$ & $\mathrm{v}$ & $\mathrm{v}$ & $\mathrm{v}$ & & $\mathrm{v}$ & $\mathrm{v}$ & & & $\mathrm{v}$ & 10 & CR \\
\hline & Rendah & & & & & & & & & & & & & & 0 & \\
\hline \multirow{4}{*}{ Keandalan Mesin } & Tinggi & & & & & & & & & & & & & & 0 & \\
\hline & Cukup Tinggi & & & & & & & & & & & & & & 0 & \\
\hline & Cukup Rendah & $\mathrm{v}$ & $\mathrm{v}$ & $\mathrm{v}$ & v & $\mathrm{v}$ & & $\mathrm{v}$ & $\mathrm{v}$ & & & $\mathrm{v}$ & $\mathrm{v}$ & $\mathrm{v}$ & 9 & CR \\
\hline & Rendah & & & & & & $\mathrm{v}$ & & & $\mathrm{v}$ & $\mathrm{v}$ & $\mathrm{v}$ & & & 4 & \\
\hline \multirow{4}{*}{ Biaya Pemeliharaan } & Tinggi & & & & & & & & & & & & & & 0 & \\
\hline & Cukup Tinggi & & & & & & & & & & & & & & 0 & \\
\hline & Cukup Rendah & & & & & & & & & & & & & & 0 & \\
\hline & \begin{tabular}{|l|} 
Rendah \\
\end{tabular} & $\mathrm{v}$ & $\mathrm{v}$ & $\mathrm{v}$ & $\mathrm{v}$ & $\mathrm{v}$ & $\mathrm{v}$ & $\mathrm{v}$ & $\mathrm{v}$ & $\mathrm{v}$ & $\mathrm{v}$ & $\mathrm{v}$ & $\mathrm{v}$ & $\mathrm{v}$ & 13 & $\mathbf{R}$ \\
\hline
\end{tabular}

Berdasarkan hasil penentuan tingkat kepentingan untuk alternatif bahan raw water filter yang diambil, maka dapat dihitung keuntungan dan kerugian dari tiap-tiap alternatif bahan raw water filter yang diambil. Keuntungan dan kerugian tiap-tiap alternatif bahan raw water filter dapat dilihat sebagai berikut :

1. Alternatif 1 (Stainless Steel)

Keuntungan dan Kerugian Alternatif 1 (Stainless Steel

\begin{tabular}{|c|c|}
\hline NO & URAIAN \\
\hline \multicolumn{2}{|c|}{ KEUNTUNGAN } \\
\hline 1 & kehandalan mesin Baik \\
\hline \multicolumn{2}{|c|}{ KERUGIAN } \\
\hline 1 & Biaya Pembelian Material Tinggi \\
\hline 2 & Tidak Ramah Lingkungan \\
\hline 3 & Umur Pakai rendah \\
\hline 4 & Biaya Pemeliharaan Tinggi \\
\hline
\end{tabular}


2. Alternatif 2 (PVC Type AW)

Keuntungan dan Kerugian Alternatif 2 (PVC Type AW)

\begin{tabular}{|r|l|}
\hline \multicolumn{1}{|l|}{ NO } & URAIAN \\
\hline \multicolumn{1}{|c|}{ KEUNTUNGAN } \\
\hline 1 & kehandalan mesin Baik \\
\hline 2 & Biaya Produksi Cukup Rendah \\
\hline 3 & Umur Pakai cukup baik \\
\hline 4 & Biaya Pemeliharaan Rendah \\
\hline KERUGIAN \\
\hline 1 & kurang Ramah Lingkungan \\
\hline
\end{tabular}

3. Alternatif 3 (PVC Type D)

Keuntungan dan Kerugian Alternatif 3 (PVC Type D)

\begin{tabular}{|r|l|}
\hline \multicolumn{1}{|c|}{ NO } & URAIAN \\
\hline \multicolumn{2}{|c|}{ KEUNTUNGAN } \\
\hline 1 & kehandalan mesin Baik \\
\hline 2 & Biaya Produksi Cukup Rendah \\
\hline 3 & Biaya Pemeliharaan Rendah \\
\hline KERUGIAN \\
\hline 1 & Umur Pakai cukup Rendah \\
\hline 2 & kurang Ramah Lingkungan \\
\hline
\end{tabular}

Perhitungan Matriks Kelayakan

Hasil Akhir Penilaian Matriks Kelayakan

\begin{tabular}{|l|c|c|c|c|c|c|c|}
\hline \multirow{2}{*}{ ALTERNATIF } & \multicolumn{7}{|c|}{ KRITERIA } \\
\cline { 2 - 9 } & By Pembelian & Lingkungan & Umur pakai & Keandalan & Pemeliharaan & TOTAL & RANKING \\
\hline STAINLESS STEEL & 53 & 42 & 99 & 92 & 82 & 368 & III \\
\hline PVC TYPE AW & 106 & 51 & 101 & 99 & 93 & 450 & I \\
\hline PVS TYPE D & 106 & 51 & 74 & 88 & 89 & 408 & II \\
\hline
\end{tabular}

Perhitungan Matriks Evaluasi

Penilaian Matriks Evaluasi

\begin{tabular}{|l|c|c|c|}
\hline \multirow{2}{*}{ ALTERNATIF } & \multicolumn{3}{|c|}{ KRITERIA } \\
\cline { 2 - 4 } & Biaya Pembelian & Umur Pakai & Lingkungan \\
\hline STAINLESS STEEL & 17 & 21 & 56 \\
\hline PVC TYPE AW & 58 & 21 & 62 \\
\hline PVS TYPE D & 58 & 21 & 39 \\
\hline
\end{tabular}

Pembobotan Kriteria

Pembobotan kriteria dilakukan dengan menggunakan metode perbandingan berpasangan Analytic Hierarchi Process berdasarkan tingkat kepentingannya, Hasil perbandingan kepentingan untuk tiap-tiap kriteria dapat dilihat dibawah ini.

Jumlah entri proses perbandingan berpasangan ditentukan sebagai berikut :

$$
\begin{aligned}
\text { Banyaknya Entri } & =\left(n^{2}-n\right) / 2 \\
& =\left(3^{2}-3\right) / 2 \\
& =3 \\
& A=\left[\begin{array}{ccc}
1 & 1 / 4 & 2 \\
4 & 1 & 4 \\
1 / 2 & 1 / 4 & 1
\end{array}\right]=\left[\begin{array}{ccc}
1 & 0.25 & 2 \\
4 & 1 & 4 \\
0.5 & 0.25 & 1
\end{array}\right]
\end{aligned}
$$

Perbandingan berpasangan diatas mengacu pada Tabel. 2.3 Tabel Skala Perbandingan dan dapat digambarkan dalam bentuk tabel skor perbandingan berpasangan sebagai berikut : 
Skor Perbandingan Berpasangan

\begin{tabular}{|c|c|c|c|}
\hline \multirow{2}{*}{ ALTERNATIF } & \multicolumn{3}{|c|}{ KRITERIA } \\
\cline { 2 - 4 } & Biaya Pembelian & Umur Pakai & Lingkungan \\
\hline Stainless Stell & 1 & $1 / 4$ & 2 \\
\hline PVC Type AW & 4 & 1 & 4 \\
\hline PVC Type D & $1 / 2$ & $1 / 4$ & 1 \\
\hline
\end{tabular}

Selanjutnya, hasil banding berpasangan kriteria matriks kelayakan dijumlahkan menurut kolom berdasarkan rumus :

$$
\frac{a_{i j}}{\sum_{i=1}^{5} a_{i j}}-\frac{a_{i j}}{a_{i j}}
$$

Hasil tersebut adalah sebagai berikut :

Penjumlahan Skor Perbandingan Berpasangan Menurut Kolom

\begin{tabular}{|c|c|c|c|}
\hline \multirow{2}{*}{ ALTERNATIF } & \multicolumn{3}{|c|}{ KRITERIA } \\
\cline { 2 - 4 } & $\begin{array}{c}\text { Biaya } \\
\text { Pembelian }\end{array}$ & Umur Pakai & Lingkungan \\
\hline Stainless Stell & 1 & 0,25 & 2 \\
\hline PVC Type AW & 4 & 1 & 4 \\
\hline PVC Type D & 0,5 & 0,25 & 1 \\
\hline$\alpha i$ & 5,5 & 1,5 & 7 \\
\hline
\end{tabular}

Hasil normalisasi untuk sel $a_{11}$ adalah

$$
\frac{a_{11}}{a_{.1}}=\frac{1}{7.833333}=0.127660
$$

Tabel Perbandingan Berpasangan yang Dinormalisasikan

\begin{tabular}{|c|c|c|c|}
\hline \multirow{2}{*}{ ALTERNATIF } & \multicolumn{3}{|c|}{ KRITERIA } \\
\cline { 2 - 4 } & $\begin{array}{c}\text { Biaya } \\
\text { Pembelian }\end{array}$ & $\begin{array}{c}\text { Umur } \\
\text { Pakai }\end{array}$ & Lingkungan \\
\hline Stainless Stell & 0,181818 & 0,166667 & 0,285714 \\
\hline PVC Type AW & 0,727273 & 0,666667 & 0,571429 \\
\hline PVC Type D & 0,090909 & 0,166667 & 0,142857 \\
\hline
\end{tabular}

a) Rataan Geometrik Kriteria (Bobot Relatif $\left(w_{\mathrm{j}}\right)$ )

- Kriteria 1

$$
\begin{aligned}
w_{1} & -G_{1}-\prod_{j=1}^{m} a_{i} \\
& =\sqrt[3]{0,181818 \times 0,166667 \times 0,285714} \\
& =0,2053395
\end{aligned}
$$

- $\quad$ Kriteria 2

$w_{2}=G_{2}=\sqrt[3]{0,727273 \times 0,666667 \times 0,571429}$

$=0,6519125$

- $\quad$ Kriteria 3

$w_{3}=G_{3}=\sqrt[8]{0,090909 \times 0,166667 \times 0,142857}$ $=0,1293558$

Berdasarkan hasil perhitungan diatas, diperoleh matriks bobot relatif yang dinormalisasikan $(W)$ sebagai berikut: 


$$
W-\left[\begin{array}{l}
0,2053395 \\
0,6519125 \\
0,1293558
\end{array}\right]
$$

i. $\quad$ Eigen Value Terbesar $\left(\lambda_{\max }\right)$

$$
\begin{aligned}
& A W=\lambda_{\max } W \\
& {\left[\begin{array}{ccc}
1 & 1 / 4 & 2 \\
4 & 1 & 4 \\
1 / 2 & 1 / 4 & 1
\end{array}\right]\left[\begin{array}{l}
0,2053395 \\
0,6519125 \\
0,1293538
\end{array}\right]=\lambda_{\max }\left[\begin{array}{l}
0,2053395 \\
0,6519125 \\
0,1293538
\end{array}\right]} \\
& {\left[\begin{array}{l}
0,6270292 \\
1,9906937 \\
0,3950036
\end{array}\right]=\lambda_{\max }\left[\begin{array}{l}
0,2053395 \\
0,6519125 \\
0,1293558
\end{array}\right]}
\end{aligned}
$$

sehingga $\lambda_{\max }$ adalah

$$
\begin{aligned}
\lambda_{\max } & =\left(\frac{0,6270292}{0,2053395}\right)+\left(\frac{1,9906937}{0,6519125}\right)+\left(\frac{0,3950036}{0,1293558}\right) \\
& =3,0536215
\end{aligned}
$$

ii. Consistency Ratio (CR)

a) Consistency Index $(\mathrm{CI})$

$C I=\frac{\lambda_{\max }-n}{n-1}=\frac{3,05.367 .15-3}{3-1}=0,0268107$

b) Consistensy Ratio (CR)

Untuk $\mathrm{n}=5$, maka nilai Ratio Index (RI) adalah 0.52 , sehingga diperoleh CR sebagai berikut:

\begin{tabular}{|c|c|c|c|c|c|}
\hline \multirow{4}{*}{ ALTERNATIF } & & KRITERI & & \multirow{4}{*}{ Pn } & \multirow{4}{*}{ RANKING } \\
\hline & $\begin{array}{c}\text { Biaya } \\
\text { Pemebelian }\end{array}$ & $\begin{array}{l}\text { Umur } \\
\text { Pakai }\end{array}$ & Lingkungan & & \\
\hline & \multicolumn{3}{|c|}{ BOBOT KRITERIA } & & \\
\hline & 0,181818 & 0,666667 & 0,142857 & & \\
\hline $\begin{array}{l}\text { STAINLESS } \\
\text { STEEL }\end{array}$ & 17 & 21 & 56 & 25,09091 & 3 \\
\hline PVC TYPE AW & 58 & 21 & 62 & 33,40259 & 1 \\
\hline PVS TYPE D & 58 & 21 & 39 & 30,11687 & 2 \\
\hline
\end{tabular}

$C R=\frac{C I}{R I}=\frac{0,0268107}{0.52}=0,0515592 \approx 0.052$

Berdasarkan hasil nilai konsistensi rasio 0.052 atau 5.2\% maka dapat dikatakan bahwa konsistensi kriteria adalah baik (dibawah toleransi indeks 10\%).

\section{Perhitungan Performansi}

Hasil Perhitungan Performansi

Tahap Pengembangan

1. Perbandingan Biaya

\begin{tabular}{|c|l|c|c|c|}
\hline NO & ALTERNATIF & BIAYA & $\begin{array}{l}\text { UMUR } \\
\text { PAKAI }\end{array}$ & $\begin{array}{c}\text { TOTAL } \\
\text { BIAYA }\end{array}$ \\
\hline 1 & $\begin{array}{l}\text { STAINLESS } \\
\text { STEEL }\end{array}$ & Rp 3.500 .000 & 8 TAHUN & Rp 3.500 .000 \\
\hline 2 & PVC TYPE AW & Rp 270.000 & 1 TAHUN & Rp 2.200 .000 \\
\hline 3 & PVS TYPE D & Rp 225.000 & 1 TAHUN & Rp. 1.800 .000 \\
\hline
\end{tabular}


2. Penentuan Nilai

Perhitungan Nilai (Value) Pada Kondisi Sebelum Perubahan Bahan Raw Water Filter

\begin{tabular}{|c|c|c|c|c|}
\hline NO & ALTERNATIF & Pn & Cn & Vn \\
\hline 1 & Steenless Steel & 25,09091 & 5.312 .500 & 1 \\
\hline
\end{tabular}

Perhitungan Nilai (Value) Pada Kondisi Setelah Perubahan Jenis pipa

\begin{tabular}{|c|c|c|c|c|}
\hline NO & ALTERNATIF & Pn & Cn & Vn \\
\hline 2 & PVC Type AW & 33,40259 & 2.160 .000 & 1,00006 \\
\hline 3 & PVC Type D & 30,11687 & 2.000 .000 & 1,00004 \\
\hline
\end{tabular}

\section{KESIMPULAN}

Berdasarkan hasil penelitian yang telah dilakukan penulis di PLTD Hative Kecil, maka dapat ditarik beberapa kesimpulan sebagai berikut :

1. Alternatif pemilihan jenis raw water filter yang akan digunakan pada PLTD hative Kecil dipilih berdasarkan alternatif yang memiliki nilai paling ekonomis. Sehingga dari pemilihan jenis raw water filter ini baiya pemeliharaan dan waktu pemeliharaan mengalami penurunan. Alternatif bahan raw water filter terpilih adalah alternatif ke 2 yaitu Penggunaan PVC Type AW sebagi Raw Water Filter dimana biaya pengadaan sebesar Rp. 2.200.000 diabndingkan dengan Steenless Stell sebesar Rp. 3.500.000 dengan periode yang sama

2. Apabila dibandingkan dengan alternatif awal, performance pada alternatif bahan raw water filter ke 2 lebih tinggi yaitu 33,40259 dengan value 1.00006 dibandingkan dengan alternatif awal dengan performansi sebesar 25,09091 dan value 1 . Hal ini menunjukkan bahwa dari sisi performansi dan nilai alternatif bahan raw water filter ke 2 jauh lebih unggul.

3. Alternatif pemilihan jenis bahan bakar yang akan digunakan pada PLTD Hative Kecil dipilih berdasarkan alternatif yang memiliki nilai paling ekonomis serta memiliki dampak yang baik terhadap lingkungan. Sehingga dari pemilihan jenis bahan raw water filter ini biaya dan waktu pemeliharaan dapat diturunkan. Alternatif bahan bakar terpilih adalah alternatif ke 2 yaitu Penggunaan bahan PVC Type AW sebagi Raw Water Filter

\section{DAFTAR PUSTAKA}

Alfa. (2015)., Analisa Keputusan. Pusat Pengembangan Bahan Ajar-Umb.

Camerling, Billi J. (2000)., Penerapan Metode Rekayasa Nilai Pada Penentuan Peralatan Trawl Kapal. Tesis Magister Teknik pada ITS Surabaya.

Heller, Edward. D., (1971)., Value Management : Value Engineering and Cost Reduction. Pillipines : Wesley Publishing Company, Inc.

Masbachul Ulum., (1996)., Penerapan Rekayasa Nilai pada Perencanaan Lambung Kapal Nelayan. Tugas Akhir pada Teknik Industri ITS Surabaya.

Miles, Lawrence. D. (1972)., Techniques of Value Engineering and Analysis (2nd ed.). New York : Mc Graw Hill Inc.

Thomas. L. Saaty (1976)., Pengambilan Keputusan Bagi Para Pimpinan. Hal 85.

Wiranto Arismunandar, Koichi Tsuda. (1986)., Motor Diesel Putaran Tinggi. Jakarta : PT. Pradnya Paramita. 
